\title{
THE REPLACEMENT OF CADMIUM COATING ON PARTS OF THE WEAPON WITH TUNGSTEN-DISULPHIDE COATING
}

Desimir Jovanović ${ }^{1 \star}$, Predrag Janković ${ }^{2}$ Miroslav Radovanović ${ }^{2}$, Stefan Đurić ${ }^{3}$

1Zastava arms, Kragujevac, Serbia

2 Faculty of Mechanical Engineering, University of Niš, Serbia

${ }^{3}$ Faculty of Engineering, University of Kragujevac, Serbia

Galvanic cadmium coatings were applied on the material in order to improve some properties such as: corrosion resistance, improved tribological properties, chemical stability, etc. The paper describes the properties of the cadmium coating and a replaceable coating as well. Cadmium is a very toxic element, so its use in EU countries and around the world is limited or completely eliminated. During the process of deposition of the cadmium coating, it is necessary to comply with the relevant legislation in order to protect living and working environment. As an alternative to cadmium coatings, zinc coatings, zinc nickel alloys, tin-zinc coatings and aluminum coatings obtained in vacuum are most commonly applied. As one of the possible replacement of the cadmium coating, there is a coating of nano-based tungsten-disulfide. The paper presents the results of testing the properties of tungsten-disulfide coatings in nanoparticles and their comparison with cadmium coatings.
(ORIGINAL SCIENTIFIC PAPER ) UDC 621.357.7:669.73:504

Keywords: cadmium coatings, tungstendisulfide coatings, nano particles, tribology, corrosion

\section{Introduction}

Galvanic coatings of cadmium are primarily used to protect steel and cast iron from corrosion, and to improve their tribological properties. Cadmium behaves anodically in relation to steel, and protects it from corrosion. It is very suitable for protection in seawater and in alkaline solutions, and is not suitable for acid media. The steel has an anode character. The thickness of the protective layer is $5-12 \mu \mathrm{m}[1]$.

Coats mostly applied from cyanide baths and cyanides, like cadmium, are listed as one of the 17 most toxic chemicals. On the cadmium coatings, a chromatic layer is applied as a supplementary protection (passivation), which requires the use of very toxic chromic acid. Coatings of cadmium have high resistance to corrosion, good adhesion, ductility and lubrication. Cadmium is very toxic, which is why it asks for limiting its application, and it completely eliminates it. Galvanic cadmium based coatings are widely used in the air and military industries [1]. Cadmium provides a good combination of protective properties in terms of a low coefficient of friction, high plasticity, lubrication and corrosion resistance [2]. However, cadmium based coatings are very harmful to the environment and ask for finding the alternative, environmentally friendly coatings that will meet the requirements of their exploitation. According to European regulations, it is foreseen that by 2020 cadmium will be completely removed from the production $[1,2]$.

Cadmium coatings are used for the anodic protection of high-strength steel parts, the protection of corrosion elements exposed to saline atmosphere, for achieving the hermeticity of the threaded elements and are especially suitable for the application to objects of complex geometry [1, 3]. Coatings based on cadmium and zinc are used for the anodic protection of high-strength steel [4]. According to literature, as alternative cadmium coatings, numerous zinc alloys containing a smaller percentage of alloying elements $\mathrm{Ni}, \mathrm{Mn}, \mathrm{Fe}, \mathrm{Co}, \mathrm{Sn}[1,5-6]$ can be used. Suitable abrasion resistance is well provided by $\mathrm{Zn}-\mathrm{Ni}$ alloys [4] while cadmium coatings have lower wear resistance and, in certain situations, they act as a solid lubricant at high loads. [1].

Dust and vapors of cadmium and its compounds act irritatingly on the mucous membrane of the respiratory and digestive tract. High concentrations cause the appearance of metallic fever, toxic pneumonitis, and toxic edema of the lungs. In chronic exposure, in addition to local irritant effects, systemic effects occur on the kidneys, liver, bones and peripheral blood. Osteomalacia and osteoporosis are the result of the damage to the kidney function, elevated concentrations of parathyroid hormone and the inhibition of some of the most important enzymes. It has been found that it is particularly dangerous to introduce cadmium into the body through respiratory organs, because it can directly cause diseases such as lung cancer, kidney dysfunction, etc. Once it is brought into the bloodstream, cadmium accumulates in kidneys causing their damage and cessation of work. [7].

Table 1 shows the effect of cadmium on human health.

\footnotetext{
*Author address: Desimir Jovanović, Zastava arms,

34000 Kragujevac, Kosovska 4, Serbia

E-mail: j.desimir@gmail.com

The manuscript received: February, 22, 2018.

Paper accepted: April, 04, 2018.
} 
In addition to reducing the limit for the permitted concentration of cadmium in the air, the regulations include the application of protective masks and other protective equipment, as well as regular medical supervision and monitoring of the health of employees [8,9].

In the Republic of Serbia, the use of cadmium and its compounds is not prohibited, although they belong to I or II poison group. According to legal regulations, the maximum permissible concentration of cadmium in the working environment is $0.05 \mathrm{mg} / \mathrm{m}^{3}$ [9]. The universal replacement of cadmium coatings has not been found yet. Electrolytic coatings (Zn, Zn-Ni, Sn-Zn, Zn-Co), vacuum coatings of aluminum and a chemical nickel coating are most often used as a replacement for cadmium coatings on steels.

Table 1. Effect of cadmium on human health [8].

\begin{tabular}{cccc}
\hline $\begin{array}{c}\text { max. allowed } \\
\text { concentration } \\
\text { Cd }\left(\mathbf{m g} / \mathbf{~ m}^{3}\right)\end{array}$ & $\begin{array}{c}\text { The } \\
\text { period }\end{array}$ & $\begin{array}{c}\text { The } \\
\text { occurrence } \\
\text { of lung } \\
\text { cancer per } \\
\mathbf{1 0 0 0} \\
\text { employees }\end{array}$ & $\begin{array}{c}\text { Thecurrence } \\
\text { of lung } \\
\text { dysfunction } \\
\text { per } 1000 \\
\text { employees }\end{array}$ \\
\hline 100 & $1971-$ & $58-157$ & 900 \\
1992 & & \\
5 & $1993-$ & $3-15$ & $14-23$ \\
\hline
\end{tabular}

In addition to the ecological acceptability, the replacement for cadmium coatings must have good tribological properties and corrosion resistance. At the Zastava Arms AD plant in Kragujevac, the tests were carried out with the coating of tungsten disulfide (Figure 1) based on nanotechnology in order to replace cadmium coating on parts of the shooting weapon. Preliminary tests under the same conditions for cadmium coatings and tungsten disulfide show the possibility of a successful replacement of harmful cadmium coatings.
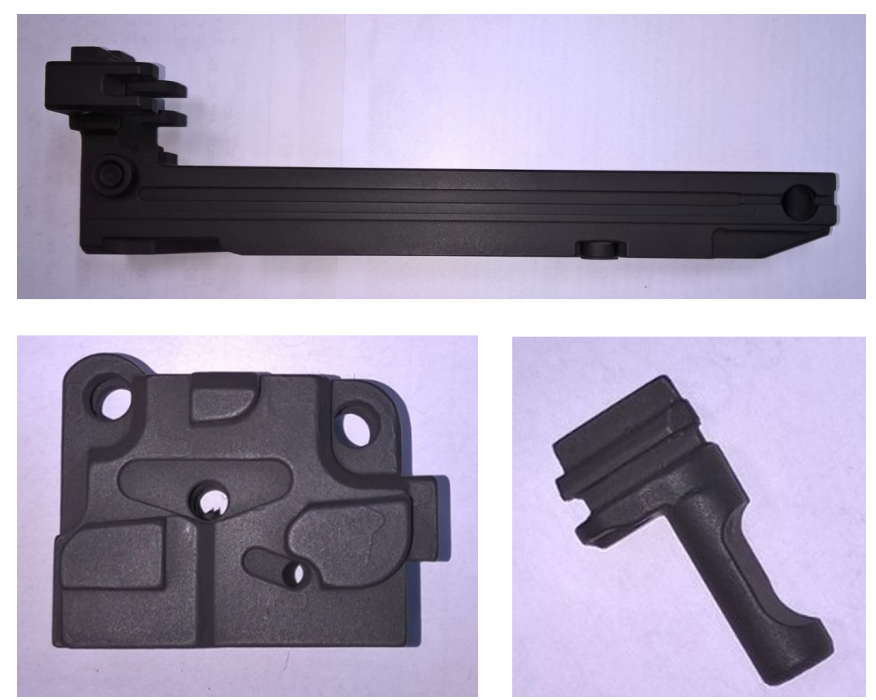

Figure 1. Parts of infantry weapons with a coating of tungsten disulfide
Tungsten disulfide, as a solid lubricant, can be applied in specific operating modes, with high temperatures, operating pressures and loads.

The development of space, air and military industries is largely based on the development of the solid lubricant tungsten disulfide coating $[10,11]$. Solid lubricants are a material that, in the form of a powder or thin film, is used to protect sliding surfaces in the function of reducing friction and wear in the process of the relative motion. The main advantage of solid lubricants is a low friction coefficient, good absorption at dynamic loads and excellent chemical stability at high temperatures. As a solid lubricant, tungsten disulfide has a number of advantages over standard lubricants [12].

\section{Experimental}

The steel C5730 (according to GOST 30HN2FA1) was selected as the basis for applying the coating. Test samples are tiles measuring $15 \times 10 \times 6.3 \mathrm{~mm}$ (according to ASTM G 77). Final processing of the samples was carried out by grinding. The microgeometry of the substrate coating is recorded on the computerized measuring device Talysurf-6, which allows complex monitoring of the contact surfaces. By using this measuring system, the information was obtained on the initial microgeometry of the contact surface of the samples. The application of galvanic coating of cadmium was carried out in the factory for galvanizing, Krusik factory in Valjevo, the zinc coating in the galvanization plant of Zastava Arms Factory in Kragujevac and the tungsten disulfide coatings in the company SPEEDUP International AD in Belgrade.

Tribological trials on the block-on-disc tribometer measured the friction coefficient and the width of the trace of the wear on the block, and thus determined the wear resistance as the wear parameter of the coated surface on the test blocks (Figure 2).

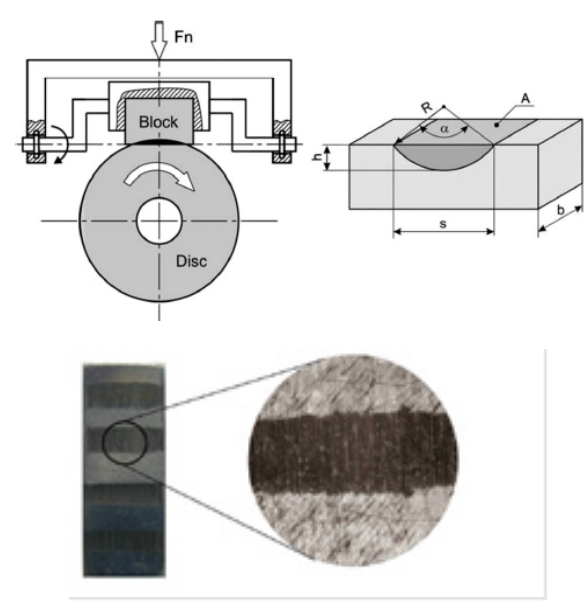

Figure 2. Trace of wear on the block

The coating wear test was performed on the TR-95 tribometer with a block-on-disk contact in the Metalwork- 
ing center for cutting and tribology at the Faculty of Engineering Sciences in Kragujevac.

Tribometer TR-95 enables the variation of contact conditions from the aspect of the shape, dimension and materials of contact elements, a normal contact load and a slip speed. The development of the wear process on the block is manifested by the formation and spreading of a pronounced trace of wear. The normal load was 6 $\mathrm{N}$, and the slip speed was $0.25 \mathrm{~m} / \mathrm{s}$. The total slip road was $450 \mathrm{~m}$.

The realized tests were with marginal lubrication with mineral hydraulic oil Hidrovisk HD-46 due to the high coefficient of friction in the case of friction without lubrication and large vibrations in the friction force measurement system at TR-95 tribrometer. In Figure 3, the friction coefficient diagrams are given depending on the transit path for the investigated coatings of cadmium and tungsten disulfide.

The cadmium coatings at the start of the test have a higher friction coefficient than the mean value. After the initial deviation, stabilization occurs. The cadmium friction coefficient has an average value of 0.27 , which is consistent with the results obtained in the paper [13]. When it comes to the wear trace width, cadmium has a lower trace.

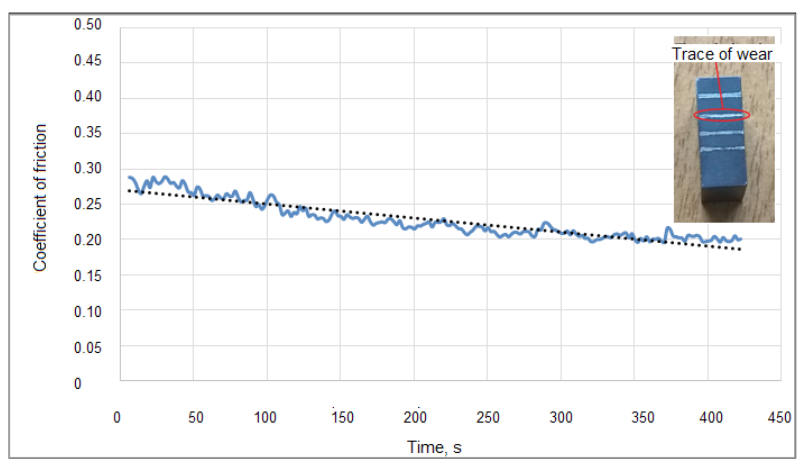

a) cadmium coating

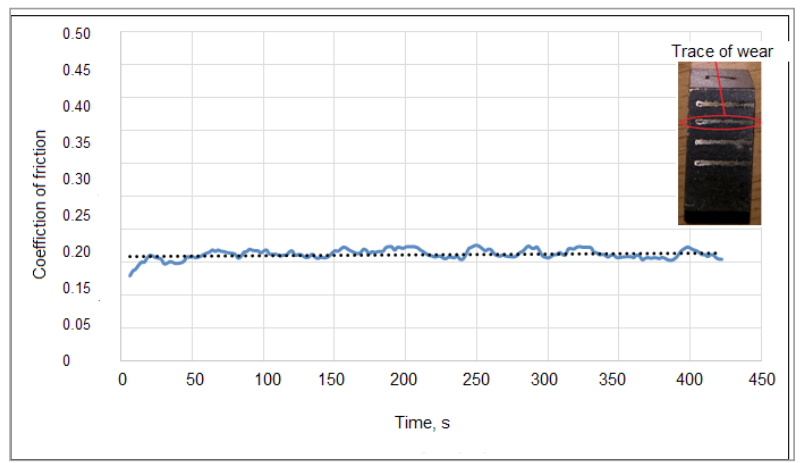

b) tungsten-disulfide coating

Figure 3. Coefficient of friction of the tested coatings

The wear resistance of the tested coatings was determined based on the volume of the worn material. The values of the volume of the trapped material for the investigated coatings of cadmium and tungsten disulfide are given in
Table 2, and the graphic representation in Figure 4.

Table 2. Volume of worn material

\begin{tabular}{ccc}
\hline Coating & Sample & Volume of worn material, $\mathbf{~ m}^{\mathbf{3}} \mathbf{\times 1 \mathbf { 1 0 } ^ { - 3 }}$ \\
\hline & 1 & 19.63588 \\
Cadmium & 2 & 30.34072 \\
Coating thickness: & 3 & 19.50134 \\
$12 \mu$ & 4 & 32.42814 \\
& 5 & 38.82106 \\
\hline \multirow{2}{*}{ Thungsten disulfide } & 6 & 64.52893 \\
Coating thickness: & 7 & 60.55432 \\
$40 \mu$ & 8 & 51.01728 \\
& 9 & 52.49307 \\
& 10 & 52.22280 \\
\hline
\end{tabular}

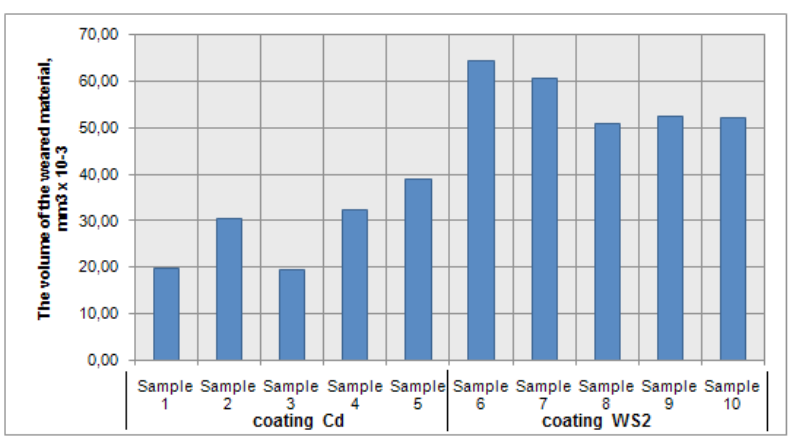

Figure 4. The volume of the weared material

\section{Results and Discussion}

The tungsten disulfide has a lower friction coefficient than cadmium (average value 0.167). Wear occurs during the block-disc contact due to uneven surfaces and roughness of the coating. During the test, the value of the friction coefficient has no significant oscillations, which is connected with self-lubricating properties of the solid lubricant. Fig. 5 presents an SEM image of cadmium and tungsten disulfide coatings before testing. During the application of the cadmium coating, solid merging of the particles that form a common structure can be observed on its surface. The particles have different sizes and moving without a defined range. The particle size and coating formation can be controlled during the coating process. The trace of wear of the cadmium coating in Fig. 6 shows that plastic deformations and the material removal result in delamination. The contact of the steel disc with the basic material indicates a complete transfer of the cadmium coating.

The tungsten disulfide has far greater particles than galvanic coatings $\mathrm{Cd}$ (Fig. 5), resulting in a rough surface and the contact surface are exclusively the irregular peaks shown in Figure 6. During the test of tungsten disulfide, abrasive wear is noted where the wearing properties of the wear fill fulfill the pores in the material.

Corrosion resistance testing was carried out at the TMO-PPT plant in Trstenik. The results of the tests are shown in Table 3. 


\begin{tabular}{|c|c|c|c|c|c|}
\hline \multirow{6}{*}{$\begin{array}{c}\text { Cadmium } \\
\text { Coating thickness: } \\
12 \mu\end{array}$} & \multirow{6}{*}{$\begin{array}{l}\text { Control parameters } \\
\text { of the salt chamber: } \\
\text { Moisture } \\
\text { temperature: } 48^{\circ} \mathrm{C} \\
\text { Chamber } \\
\text { temperature: } 35^{\circ} \mathrm{C} \text {, } \\
\mathrm{pH}: 6.7\end{array}$} & CK & - & - & - \\
\hline & & BK & - & - & - \\
\hline & & OK & 1.2.3.4.5 & 1.2.3.4.5 & 1.2.3.4.5 \\
\hline & & Date & 07.02 .2017 & 08.02 .2017 & 09.02 .2017 \\
\hline & & $\begin{array}{c}\text { Time } \\
\text { (h) }\end{array}$ & 24 & 48 & 72 \\
\hline & & CK & - & - & 9.13 .16 .17 .47 \\
\hline \multirow{4}{*}{$\begin{array}{l}\text { Thungsten disulfide } \\
\text { Coating thickness: } \\
\qquad 40 \mu\end{array}$} & Test parameters: & BK & - & - & - \\
\hline & Salt chamber & OK & 9.13 .16 .17 .47 & 9.13 .16 .17 .47 & - \\
\hline & inclusion date: & Date & 07.02 .2017 & 08.02 .2017 & 09.02 .2017 \\
\hline & $\begin{array}{l}\text { Number of pieces: } 5 \\
\text { Requirement: no red } \\
\text { corrosion: } 72 \mathrm{~h} \\
\text { S / ISO } 9227\end{array}$ & $\begin{array}{c}\text { Time } \\
\text { (h) }\end{array}$ & 24 & 48 & 72 \\
\hline ग10 & ; BK-white corrosic & & torions & & d uit \\
\hline
\end{tabular}

Table 3. Corrosion resistance tests
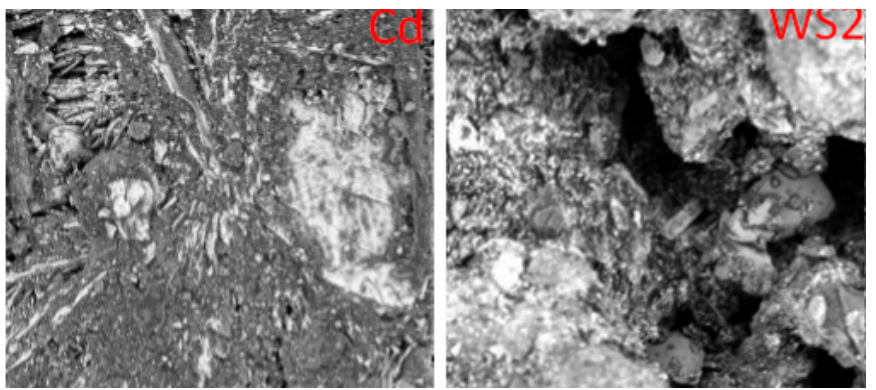

Figure 5. SEM surface of the coating prior to testing
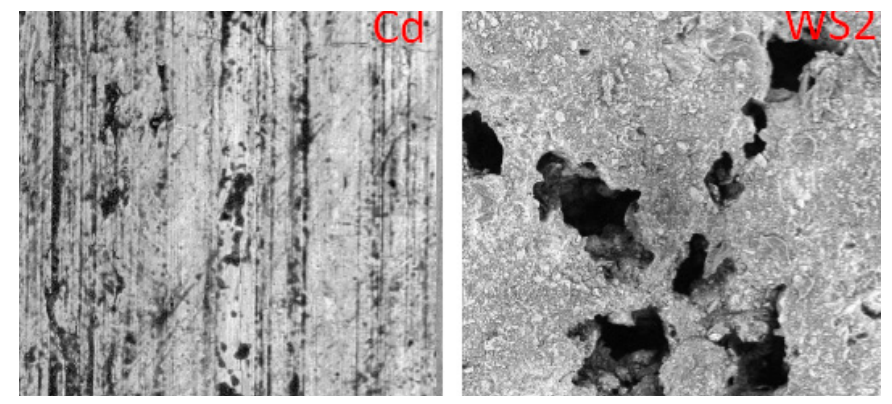

Figure 6. SEM surface of the trace of wear

Figure 7 shows the appearance of cadmium and tungsten disulfide coatings after the corrosion resistance test of $48 \mathrm{~h}$. There are no traces of corrosion on the surface of the tile.
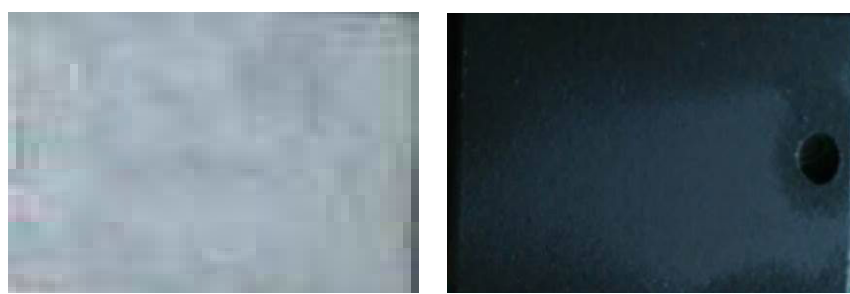

Figure 7. Appearance of the coating after $48 \mathrm{~h}$, in the salt chamber
Figure 8 shows the appearance of tungsten disulfide coatings after the corrosion resistance test of $72 \mathrm{~h}$. Corrosion traces can be observed on the tile surfaces.

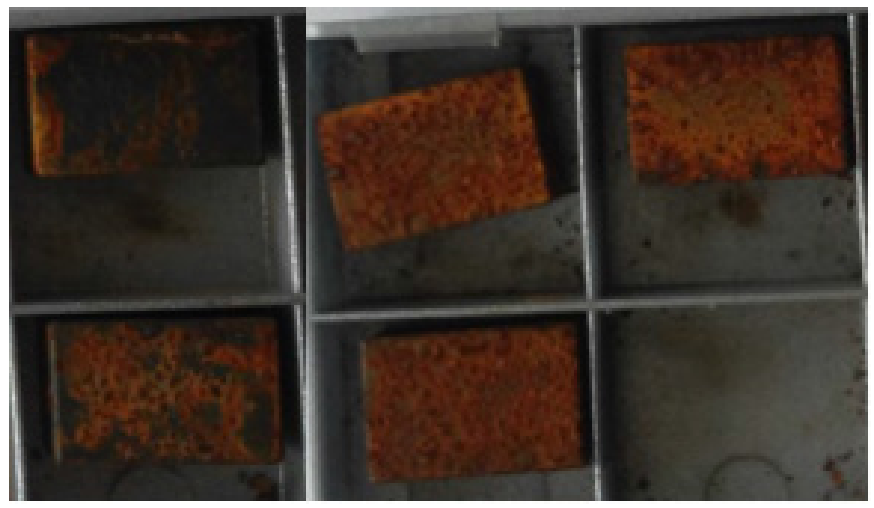

Figure 8. Appearance of the coating of tungsten disulfide after $72 \mathrm{~h}$, in the salt chamber

\section{Conclusion}

In these investigations, tribological and corrosion characteristics of tungsten-disulfide coatings in nano form were examined. The following results were obtained as a result of the research:

- The coefficient of friction of the tungsten-disulfide coating is lower than that of cadmium.

- The weariness is more about the coating of tungstendisulphide on the nano-base compared to the galvanic coating of cadmium.

- When it comes to the corrosion resistance, cadmium coatings have the significantly better resistance, 72 hours in a salt-free chamber of corrosion, compared to the tungsten-disulfide coating which lasted for satisfactory 42 hours.

The obtained results in the research indicate a wide range of possibilities for the application of the tungstendisulfide coating onto the nano base. During the load, there is no major damage and coating of the coating which, with a small coefficient of friction and relatively 
good corrosion resistance, completely overcomes this coating as a potential substitute for harmful coatings of cadmium. There is still no universal replacement for cadmium coatings.

\section{References}

[1] K. Sriraman, H. Strauss, S. Brahimi, S. Chromik, J. Szpunar, J. Osborne, S. Yue. Tribological behavior of electrodeposited $\mathrm{Zn}, \mathrm{Zn}-\mathrm{Ni}, \mathrm{Cd}$ and $\mathrm{Cd}-\mathrm{Ti}$ coatings on low carbon steel substrates, Tribology International, 56 (2012) 107-120.

[2] A. Agüero, J.C. del Hoyo, J. García de Blas, M. García, M. Gutiérrez, L. Madueño, S. Ulargui. Aluminum slurry coatings to replace cadmium for aeronautic applications, Surface \& Coatings Technology, 213 (2012) 229-238.

[3] A. D. Zhirnov, S. A. Karimova, L. V. Ovsyannikova, O. A. Gubenko. New protective coatings for replacing cadmium coatings on steel parts, Metal Sciense and Heat Treatment, 45 (1-2) (2003) 21-24.

[4] N.C.Panagopoulos, G. K. Georgarakis, E. P.Agathocleous Sliding wear behaviourof zinc-nickel alloy electrodeposits, Tribology International, 36 (2003) 619-23.

[5] A. Conde, M. A. Arenas, J. J. de Damborenea. Electrodeposition of $\mathrm{Zn}-\mathrm{Ni}$ coatings as $\mathrm{Cd}$ replacement for corrosion protection of high strength steel, Corrosion Science, 53 (2011) 1489-1497.
[6] A. C. Hegde, K. Venkatakrishna, N. Eliaz. Electrodeposition of $\mathrm{Zn}-\mathrm{Ni}, \mathrm{Zn}-\mathrm{Fe}$ and $\mathrm{Zn}-\mathrm{Ni}-\mathrm{Fe}$ alloys, Surface \& Coatings Technology, 205 (2010) 2031-2041.

[7] R. Kovačević, S. Milačić, D. Jovičić, I. Tanasković: Savremeni aspekti patogenetskih mehanizama delovanja metala na ljudski organizam tokom profesionalne ekspozicije, Zaštita materijala, 46 (1) (2005) 51-54.

[8] W. M. Ingle. Cadmium Elimination, Surface Engineering Vol. 5, ASM Handbook, Ed., ASM International, (1997) 918-924.

[9] Z. Šegrt. Otrovne hemikalije, Punto-Beograd, 2004.

[10] G. Y.Du, D.C. Ba, Z. Ta, K, Lui: Research on frictional behavior of tungsten disulfide thin films prepared by RF magnetron sputtering on restless steel, Physics Procedia, 32 (2012) 532-538.

[11] S. Đuric, B. Trifunovic, B. Nedic, D. Jovanovic, A. Kostic. Tribological characteristics of galvanic coatings and coatings of tungsten disulfide, Proceedings: $15^{\text {th }}$ International conference on Tribology, SERBIATRIB'15, Kragujevac, (2017) 698-703,.

[12] Y. Lian, J. Deng, G. Yan. Preparation of tungsten disulfide (WS 2 ) soft-coated nano-textured self-lubricating tool and its cutting performance, Int. J. Adv. Manuf. Technol., Vol. 68 (2013) 2033-2042.

[13] S. Jahanmir, E. P. Abrahamson, N. P. Suh. Sliding wear resistance of metallic coated surfaces, Wear, 40 (1) (1976) 75-84.

Izvod

\section{ZAMENA PREVLAKA KADMIJUMA NA DELOVIMA ORUŽJA PREVLAKAMA VOLFRAM-DISULFIDA}

Desimir Jovanović ${ }^{1}$, Predrag Janković ${ }^{2}$ Miroslav Radovanović ${ }^{2}$, Stefan Đurić

1Zastava oružje, Kragujevac, Srbija

${ }^{2}$ Mašinski fakultet, Univerzitet u Nišu, Srbija

${ }^{3}$ Fakultet inženjerskih nauka, Univerzitet u Kragujevcu Nišu, Srbija

Galvanske prevlake kadmijuma se nanose da bi površina osnovnog materijala dobila odgovarajuća svojstava, kao što su: otpornost prema koroziji, poboljšana tribološka svojstva, hemijska postojanost, i dr. U radu su razmotrene osobine prevlake kadmijuma i osobine prevlaka koje mogu da je zamene. Kadmijum je veoma toksičan, pa se njegova upotreba u zemljama EU i širom sveta ograničava ili potpuno eliminiše. Tokom procesa taloženja prevlaka kadmijuma neophodno je pridržavati se odgovarajuće zakonske regulative u cilju zaštite životne i radne sredine. Kao alternativa prevlakama kadmijuma najčešće se primenjuju prevlake cinka, prevlake legura cink-nikal, kalaj-cink, kao i prevlake aluminijuma dobijene u vakuumu. Kao jedna od mogućih zamena prevlake kadmijuma je i prevlaka volfram-disulfida na bazi nano čestica. $U$ radu su prikazani rezultat $\mathrm{i}$ ispitivanja karakteristika prevlaka volfram-disulfida u nano obliku ii njihovo poređenje sa prevlakama kadmijuma
(ORIGINALNI NAUČNI RAD) UDK 621.357.7:669.73:504

Ključne reči: prevlake kadmijuma, prevlake volfram-disulfida, nano čestice, tribologija, korozija 